\title{
HLA-DR antigen detection in giant cell lesions
}

\section{J. A. Regezi', R. J. Zarbo ${ }^{3}$, R. V. Lloyd $^{2}$}

Departments of ${ }^{1}$ Oral Pathology and ${ }^{2}$ Pathology, University of Michigan, Ann Arbor, ${ }^{3}$ Department of Pathology, Wayne State University/Harper Hospital, Detroit, Michigan, U.S.A.
Regezi JA, Zarbo RJ, Lloyd RV. HLA-DR Antigen detection in giant cell lesions. J Oral Pathol 1986: 15: 434-438.

Sixty-six giant cell lesions ranging from inflammatory to neoplastic were evaluated for HLA-DR antigens using formalin/paraffin tissue and a monoclonal antibody labelled by the avidin-biotin peroxidase. HLA-DR antigens were expressed in nearly all lesions, predominantly on round, macrophage-like cells. Granulomatous inflammatory lesions were generally more immunoreactive than non-inflammatory lesions. Multinucleate giant cells were relatively unreactive in non-inflammatory lesions as compared to inflammatory lesions. Determination of HLA-DR expression does not appear to be helpful in discriminating between the various giant cell lesions.
Joseph A. Regezi, DDS, MS, Department of Oral Pathology, School of Dentistry, University of Michigan, Ann Arbor, Michigan 48109-1078, U.S.A.

Accepted for publication June 3, 1986
HLA-DR antigens (human Class II major histocompatibility antigens), necessary for the regulation of T-celldependent immune responses, are normally expressed on the surfaces of $B$ cells, activated T-cells, macrophages, Langerhans cells, and endothelial cells (1). These antigens have also been detected on several types of non-lymphoid cells (2-5). The synthesis and expression of HLA-DR antigens on normal cells that are not part of the immune system remains to be fully explained. There is, however, evidence that under certain immunologic inductive influences, these otherwise unreactive cells may express HLA-DR antigens and contribute to enhancement or amplification of the immune response through lymphocyte coordination and antigen presentation (6-11). Also, expression of HLA-DR antigens by normal non-immune cells has been implicated in the mediation of some autoimmune diseases $(9,12)$. A positive correlation has been documented between HLA-DR expression in thyroid epithelium and lymphocytic infiltrates in autoimmune Grave's disease and Hashimoto's disease $(3,13)$.

HLA-DR antigens have been detected on the cells of many neoplasms such as melanoma $(14,15)$, carcinoma of the lung (15), eosinophilic granuloma $(16,17)$, papillary carcinoma of the thyroid (13), and lymphoma (18, 19). Expression of HLA-DR antigens in eosinophilic granuloma and lymphoma may be explained, in part, by the origin of these neoplasms from cells that normally express these antigens.
For the other neoplasms, expression may be related to an, as yet, undetermined immunoregulatory role played by the neoplastic cells.

Detection of HLA-DR antigens in neoplasms which are derived from cells that normally do not express these antigens suggests the possibility that detection of HLA-DR antigens may be a useful diagnostic tool. In neoplasms derived from cells which are normally positive, alterations in HLA-DR expression may be useful in studies of differentiation and in tumor classification.

Numerous giant cell lesions are encountered in bone and soft tissue. Thecombination of multinucleate giant cells and macrophages in a benign fibroblastic matrix common to all these lesions makes them difficult to differentiate with conventional histologic tissue sections. Immunotyping of the various giant cell lesions for macrophage markers, such as HLA-DR, may be useful in microscopic diagnosis. It may also provide information relative to their pathogenesis. The purposes of this investigation are: 1) to evaluate a variety of neoplastic and reactive giant cell lesions for HLA-DR antigens and 2) to determine if HLA-DR expression may be helpful in the diagnosis and classification of giant cell lesions.

\section{Material and methods}

Formalin-fixed, paraffin-embedded surgical specimens of giant cell lesions of bone and soft tissue were retrieved from the files of the University of Michigan and Detroit-Harper Hospi- tals. Five micron sections mounted on Sobo glue covered slides were evaluated for HLA-DR antigens using an immunoperoxidase technique. Lesions, included were: 21 gingival peripheral giant cell granulomas (PGCG), 21 central giant cell granulomas of the jaws (CGCG), 6 giant cell tumors of long bone (GCT), 1 osteitis fibrosa cystica of the mandible (OFC), 1 aneurysmal bone cyst of long bone (ABC), 3 cases of cherubism of the jaws, 3 giant cell tumors of tendon sheath of the hand (GCTTS), and a variety of soft tissue granulomatous inflammatory lesions which included 5 foreign body granulomas (2 from skin and 3 from oral mucosa), one tuberculous cervical lymph node, and 2 cases of Crohn's disease (1 from oral vestibular mucosa and 1 from rectum). Tissue sections were dewaxed, treated with a solution of equal parts of $3 \%$ hydrogen peroxide and methanol, washed with phosphate buffered saline (PBS), and treated with $5 \%$ horse serum. Tissue was then incubated over night $(16 \mathrm{~h})$ at $4^{\circ} \mathrm{C}$ with monoclonal antibody (supernatant fluid from spent culture medium used undiluted) to HLA-DR antigens (15) (gift from Dr. B. Wilson, University of Michigan).

After a PBS wash, sections were incubated for $30 \mathrm{~min}$ with a 1:200 dilution of biotinylated antimouse $\mathrm{IgG}$ followed by a PBS wash and incubation for 30 min with avidin-biotin peroxidase (10 $\mu \mathrm{g} / \mathrm{ml}$ avidin with $3 \mu \mathrm{g} / \mathrm{ml}$ biotinylated peroxidase, Vector laboratory, Burlingame, California). After a PBS wash, sections were developed in aminoethyl- 
Table 1. HLA-DR immunoreactivity of giant cell lesions.

\begin{tabular}{lccc}
\hline & $\begin{array}{c}\text { Multinucleate } \\
\text { giant cells }\end{array}$ & $\begin{array}{c}\text { Mononuclear } \\
\text { Stromal cells }\end{array}$ & $\begin{array}{c}\text { Total/Total } \\
\text { Positive/tested }\end{array}$ \\
\hline PGCG & $1^{*}$ & $19^{* *}$ & $19 / 21$ \\
CGCG & $2^{*}$ & $19^{* *}$ & $19 / 21$ \\
GCT & 0 & $4^{* *}$ & $4 / 6$ \\
OFC & 0 & $1^{* *}$ & $1 / 1$ \\
ABC & 0 & $1^{* *}$ & $1 / 1$ \\
Cherub. & $2^{* *}$ & $3^{* *}$ & $3 / 3$ \\
GCTTS & 0 & $3^{* *}$ & $3 / 3$ \\
Gran. Inflam. & $2^{* * * * *}$ & $5^{* *}$ & $5 / 5$ \\
Foreign body & $1^{* * *}$ & $1^{* * *}$ & $1 / 1$ \\
T.B. & $1^{* * * * * *}$ & $2^{* * *}$ & $2 / 2$ \\
Non-specific & $2^{* * * *}$ & & $2 / 2$ \\
\hline Crohn's & & & $60 / 66$ \\
\hline
\end{tabular}

\footnotetext{
*Slight immunoreactivity-scattered positive cells.

** Moderate immunoreactivity-less than $25 \%$ of cells positive.

*** * Moderately-intense reactivity-25-50\% of cells positive

***** Intense immunoreactivity-more than $50 \%$ of cells positive.
}

carbazole $(.4 \mathrm{gm} / 100 \mathrm{ml}$ dimethylformamide in . $1 \mathrm{M}$ acetate buffer, $\mathrm{pH} 5.2$, with hydrogen peroxide, Sigma, St. Louis, Missouri) for $15 \mathrm{~min}$. Sections were then rinsed, counterstained with Mayer's hematoxylin and mounted with glycerol-gelatin. Negative controls included replacement of primary antibody with mouse myeloma proteins (Miles Scientific, Napercille, Illinois) and omission of biotinylated immunoglobulin or avidin-biotin-peroxidase complex. Mononuclear and multinucleate cells were evaluated at $400 \times$ for positive reactivity.

\section{Results}

In general, some HLA-DR expression was noted in almost all giant cell lesions (Table). Reactivity ranged from slight (focal), in which only a few scattered positive cells were found, to intense (diffuse), in which more than half the prevalent pattern was one in which giant cells were negative and less than $25 \%$ of the mononuclear cells were positive. Staining intensity of individual positive cells was uniformly high; differences were primarily in the numbers of positive cells.

Monuclear stromal cell staining was cleate giant cell staining was both membranous and cytoplasmic. Intense staining of giant cells was generally found in especially in two foreign body reactions (one known to be caused by silicone, Fig. 2), in tuberculous lymphadenitis (Fig. 3), and in Crohn's disease. Immucells were positive (Fig. 1). The most usually membranous, while multinugranulomatous inflammatory lesions, noreactive giant cells were rarely found in any of the other lesions studied. When present, they were usually binucleate or trinucleate forms.

Round, macrophage-like, mononuclear cells were the most frequently encountered positive cells and were found in all cases that showed immunoreactivity. However, spindle, fibroblast like, mononuclear cells were frequently positive but were less prominent than positive round cells. Positive dendritic cells were also found in one central giant cell granuloma, one peripheral giant cell granuloma (Fig. 4), and two cases of cherubism.

As a whole, granulomatous inflammatory lesions showed more intense immunoreactivity than other giant cell lesions.

Peripheral giant cell granuloma could not be separated from central giant cell granuloma. Also, central giant cell granuloma of the jaws could not be separated from giant cell tumor of long bone.

From the results of this study, it is apparent that as a group, giant cell lesions exhibit HLA-DR antigens. The PGCG, CGCG, CGT, OFC, ABC, cherubism, and GCTTS showed similar patterns of HLA-DR expression; the vast majority of positive cells were round macrophage-like cells with only rare positive dendritic or giant cells being noted. One or more of the following mechanisms may be involved in HLA-DR expression in these lesions: 1) The same or closely related HLA-DR positive cells could give rise to or participate in the development of the different giant cell lesions; 2) expression of HLA-DR antigens by tumors cells could result from induction by a mediator released from immunocompetent cells reacting to tumor cell proliferation (8-11); a mechanism proposed for enhanced im-

\section{Discussion}

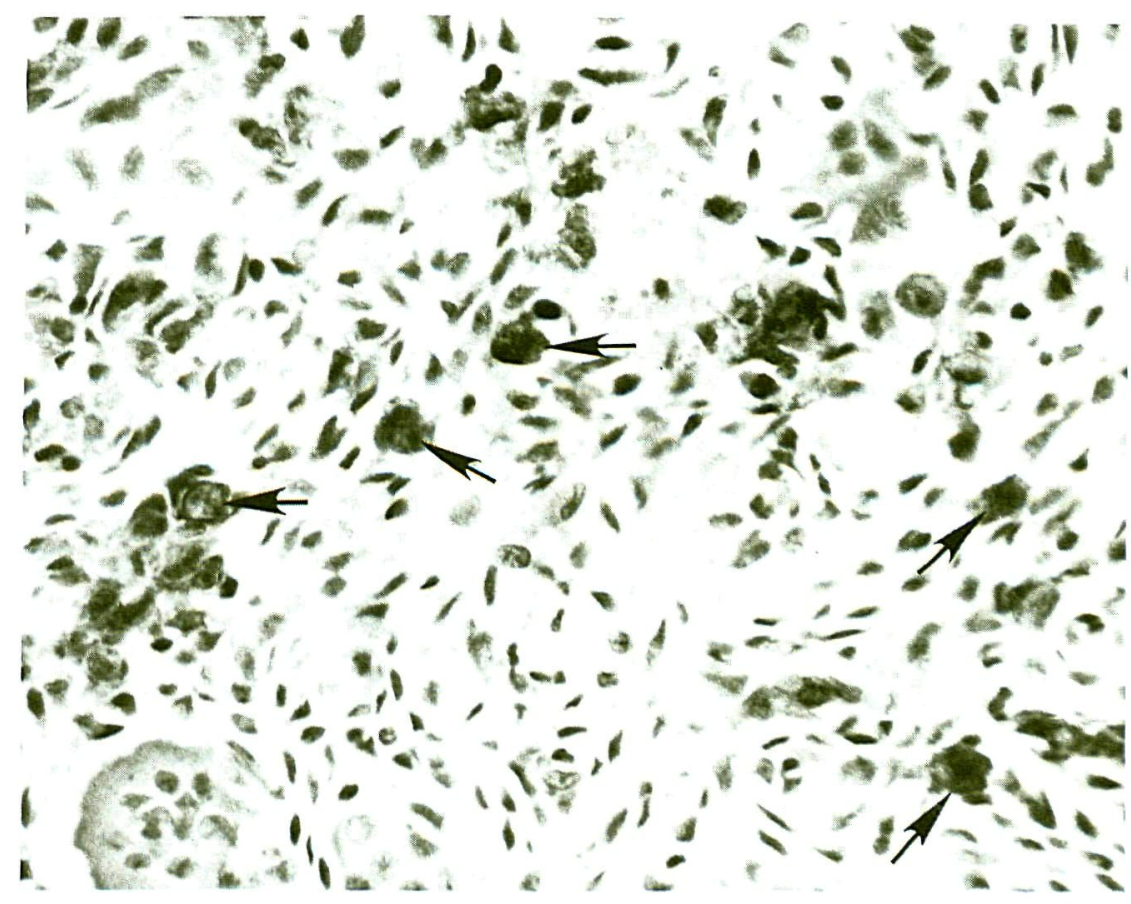

Fig. 1. Central giant cell granuloma immunostained for HLA-DR antigens. Several mononuclear cells show membrane and cytoplasmic staining (arrows) $(\times 400)$. 


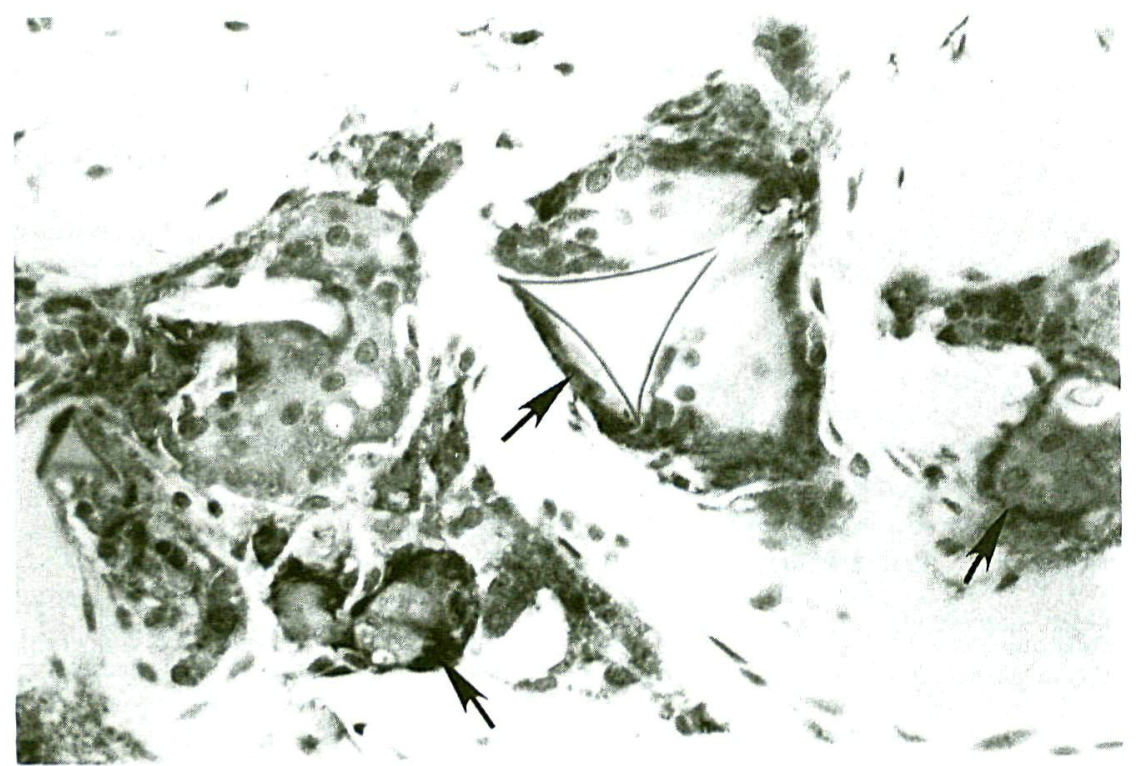

Fig. 2. HLA-DR immunoreactivity in foreign body reaction to silicone. Note intense membrane staining in multinucleate giant cells (arrows) $(\times 400)$.

munological response to melanoma (20); 3) the HLA-DR expression could be due to secondary infiltration of the lesions by HLA-DR positive macrophages as part of an immune response to tumor antigens $(21,22)$.

The difference in antigen staining patterns, membranous versus cytoplasmic, can be explained through intracellular antigen synthesis with subsequent surface expression. Alternately, cytoplasmic staining could follow ingestion of membrane antigen. The former is favored because it is likely that intracellular production of this antigen is induced by chemical mediators (8-11).

The general low level of immunoreactivity of the lesions studied may be due to one or more factors. Less than ideal tissue fixation may negatively affect antigen expression. This, however, may not have been significant since the comparably stained inflammatory lesion showed intense staining. Heterogeneity of antigen expression by the tumor cells, a phenomenon noted in both normal and neoplastic macrophages $(23,24)$, could also contribute to the generally low immunoreactivity of the giant cell lesions. Finally, if the non-inflammatory lesions are, in fact, composed of neoplastic macrophages or related cells, reduced HLA-DR expression may be related to cellular dysfunction.

giant cell granuloma share many morphologic and histochemical features (25-28). In addition to acid phosphatase positive giant cells, two mononu- the possibility that Langerhans cells may have a role in the development of some of these lesions.

In one case report, a monoclonal antibody developed to identify a macrophage antigen labelled the multinucleate giant cells of a giant cell tumor of long bone (21). Other macrophage markers (muramidase, $\alpha-1$ antitrypsin, $\mathrm{C} 3, \mathrm{Fc}$ ) have generally been absent in multinucleate giant cells of giant cell tumors $(21,23,30)$. This lack of reactivity of giant cells was also noted relative to HLA-DR antigens in the non-inflammatory lesions of this study. This difference may be related to immunologically inactive and/or physiologically aged giant cells in these lesions (31-33).

It is generally believed that multinucleate cells in giant cell lesions are derived from mononuclear cells (macrophages or related cells) $(21,26,27$, $34)$. The findings in this study are consistent with this concept based on the co-expression of HLA-DR antigens on mononuclear macrophages and multinucleate giant cells. The finding of binuclear and trinuclear giant cells in non-inflammatory giant cell lesions suggests that newly formed cells initially retain HLA-DR activity and that this activity is subesequently lost as these cells age (acquire more nuclei) $(31,32)$.

Giant cell lesions of the jaws which

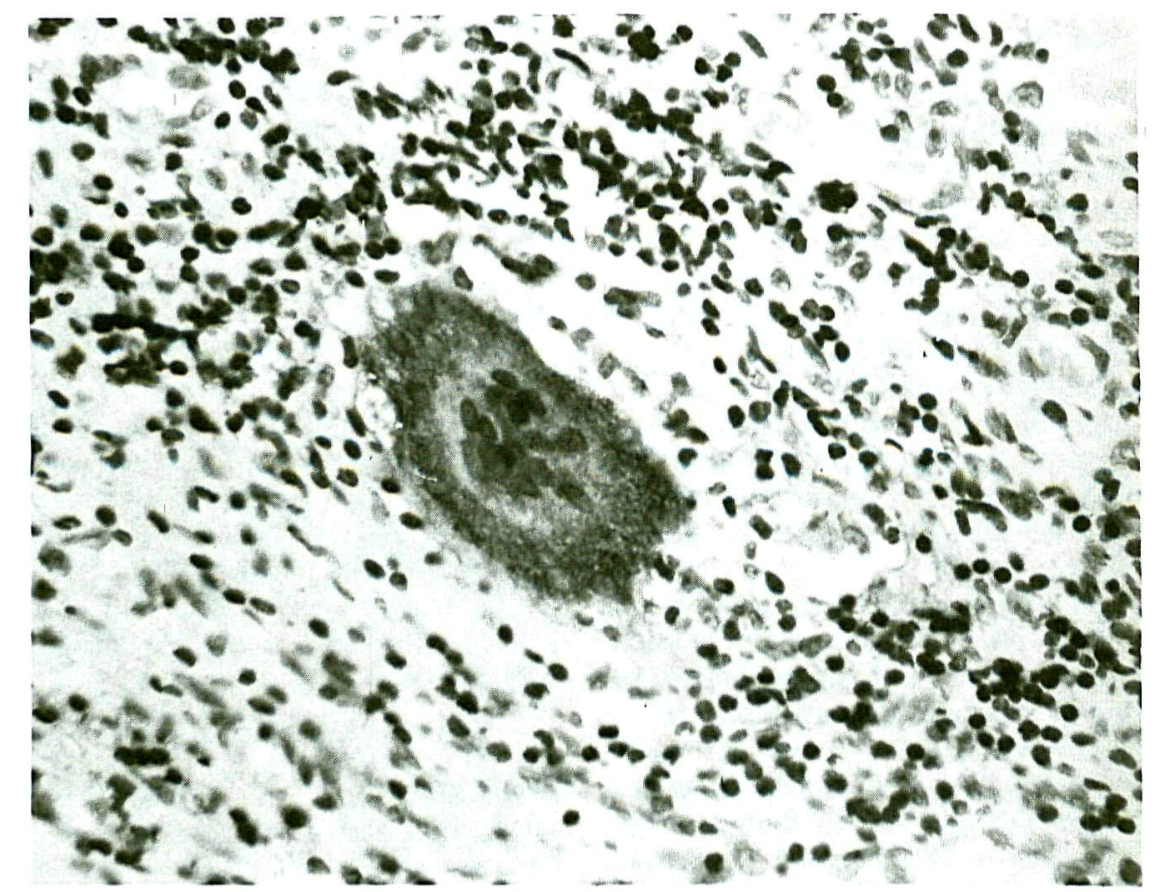

Fig. 3. Peripheral cytoplasmic HLA-DR staining of giant cell in granuloma of tuberculous lymphadenitis $(\times 400)$. 


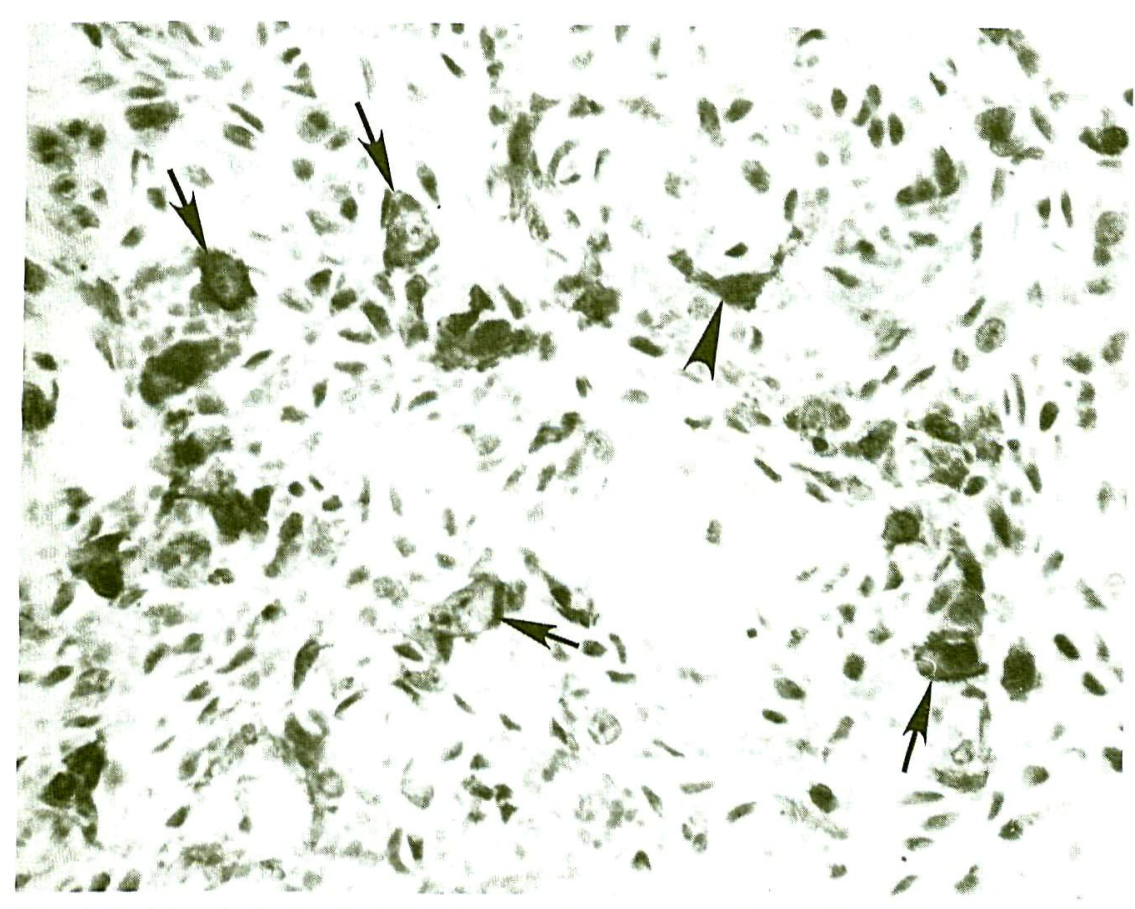

Fig. 4. Peripheral giant cell granuloma showing numerous HLA-DR positive mononuclear cells (arrows). Note HLA-DR positive dendritic cell (arrow head) $(\times 400)$.

range from congenital to reactive to neoplastic can be problematic for the pathologist because of their markedly similar histopathologic appearances. Unfortunately, HLA-DR antigens do not appear to be an indicator of differentiation within this group of lesions. Determination of HLA-DR antigen expression does not appear to be helpful in the separation of these clinically diverse lesions.

It is concluded that 1) most giant cell lesions exhibit HLA-DR immunoreactivity, 2) inflammatory giant cell lesions are generally more immunoreactive than other giant cell lesions, and 3) multinucleated giant cells are relatively non-reactive in neoplastic lesions.

Acknowledgement - The authors gratefully acknowledge the assistance given them by Jane Folske in manuscript preparation and by Julie Haveri in tissue preparation.

\section{References}

1. Winchester R, Kunkel H. The human la system. Adv Immunol 1979: 28: 221.

2. Daynes R, Emam M, Krueger G, Roberts $L$. Expression of Ia antigen on epidermal keratinocytes after the grafting of normal skin to nude mice. J Immunol 1983: 130: 1536.

3. Hanafusa T, Chiovato L, Doniach D, Pujol-Borrell R, Russell R, Bottazzo G. Aberrant expression of HLA-DR anti- gen on thyrocytes in Grave's disease: relevance for autoimmunity. Lancet 1983: 2: 1111

4. Walsh L, Seymour G, Powell R. Gingival keratinocytes express HLA-DR antigens in chronic gingivitis. J O Pathol 1985: 14: 315 .

5. Wiman K, Curman B, Forsum U, Klareskog U, Malnas-Tjernlund $\mathrm{L}$, Tragardh L, Peterson P. Occurance of la antigens on tissues of non-lymphoid origin. Nature 1978: 276: 711.

6. Barclay N, Mason D. Graft rejection and Ia antigens-paradox resolved ? 1983 Nature: 303: 382.

7. Basham $T$, Nickoloff $B$, Merigan $T$, Morhenn V. Recombinant gamma interferon induces HLA-DR expression on cultured human keratinocytes. J Invest Derm 1984: 83: 88 .

8. Geboes K, Kutgeerts P, Stessens L, Vantrappen G, Desmet V. Expression of MHC class II antigens by oesophageal epithelium in herpes simplex ocsophagitis. Histopathol 1985: 9: 711.

9. Rosa F, Fellous M. The effect of gamma-interferon on MHC antigens. Immunol Today 1984: 5: 261.

10. Todd I, Pujol-Borrell R, Hammond L. Bottazzo G. Interferon- $\gamma$ induces HLA-DR expression by thyroid epithelium. Clin Exp Immunol 1985: 61: 265.

11. Vole-Platzer B, Leibl H, Luger T, Zahn G, Stingl G. Human epidermal cells synthesize HLA-DR alloantigens in vitro upon stimulation with $\gamma$-interferon. J Invest Derm 1985: 85: 16.

12. Bottazzo G, Pujol-Borrell R, Hanafusa T. Role of aberrant HLA-DR expres- sion and antigen presentation in induction of endocrine autoimmunity. Lancet 1983: 2: 1115.

13. Lloyd R, Johnson T, Blaivas M, Sisson $J$, Wilson B. Detection of HLA-DR antigens in paraffin embedded thyroid epithelial cells with a monoclonal antibody. Am J Pathol 1985: 120: 106.

14. Thompson J, Herlyn M, Elder D, Clark W, Steplewski Z, Koprowski. Expression of DR antigens in freshly frozen human tumors. Hybridoma 1982: I: 161.

15. Wilson B, Herzig M, Lloyd R. Immunoperoxidase staining for la-like antigens in paraffin embedded tissues from human melanoma and lung carcinoma. Am J Pathol 1984: 115: 102.

16. Beckstead J, Wood G, Turner R. Histiocytosis $X$ and Langerhans cells: enzyme histochemical and immunologic similarities. Hum Pathol 1984: 15: 826.

17. Schuler G, Stingl G, Aberer W, StinglGazze L, Honigsmann H. Wolff K. Histiocytosis $X$ cells in eosinophilic granuloma express Ia and T6 antigens. J Invest Derm 1983: 80: 405.

18. Foon K, Schroff R, Gale R. Surface markers on leukemia and lymphoma cells: recent advances. Blood 1982: 60: 1.

19. Marder R, Variakojis D, Silver J, Epstein A. Immunohistochemical analysis of hman lymphomas with monoclonal antibodies to $B$ cell and Ia antigens reactive in paraffin sections. Lab Invest 1985: 52: 497.

20. Taramelli D, Fossati G, Mazzocchi A. Delia D, Ferrone S, Parmiani G. Classes I and II HLA and melanoma-associated antigen expression and modulation on melanoma cells isolated from primary and metastatic lesions. Cancer Res 1986: 46: 433.

21. Athanasou N, Bliss E, Gatter K. Heryet A. An immunological study of giant cell tumour of bone: evidence for an osteoclast origin of the giant cells. J Pathol 1985: 147: 153.

22. Roessner A, Bassewitz B, Schlake W, Thorwesten G, Grundmann E. Biologic characterization of human bone tumors III. Giant cell tumor of bone. Path Res Pract 1984: 178: 431.

23. Brooks J, Pascal R. Malignant giant cell tumor of bone: Ultrastructural evidence of histiocytic origin. Human Pathol 1984: 15: 1098 .

24. Mason D, Taylor C. The distribution of muramidase (lysozyme) in human tissues. J Clin Pathol 1975: 28: 124.

25. Aparisi T, Arborgh B, Ericksson J. Giant cell tumor of bone: variations in patterns of appearance of different cell types. Virch Arch A Path Anat Hist 1979: 38: 159.

26. El-Mofty S, Osdoby P. Growth behavior and lineage of isolated and cultured cells derived from giant cell granuloma of the mandible. J Oral Pathol 1985: 14: 539 . 


\section{Regezi et al.}

27. Hanaoka H, Friedman B, Mack R. Ultrastructure and histogenesis of giant cell tumor of bone. Cancer 1970: 25: 1408.

28. Schajowicz F. Giant cell tumors of bone (osteoclastoma). J Bone Joint Surg 1961: 43-A: 1.

29. El-Labban N, Lee K. Myofibroblasts in central giant cell granuloma of the jaws: an ultrastructural study. 1983: 7: 907.
30. Wood G, Neff J, Gollahon K, Gourley W. Macrophages in giant cell tumours of bone. J Pathol 1978: 125: 53.

31. Mariano M, Nikitin T, Malucelli B. Immunological and non-immunological phagocytosis by inflammatory macrophages, epitheliod cells and macrophage polykaryons from foreign body granulomata. J Pathol 1976: 120: 151.

32. Papadimitriou J. Detection of macroph- age receptors for heterologous IgG by scanning and transmission electron microscopy. J Pathol 1973: 110: 213.

33. Papadimitriou J, Robertson $\mathrm{T}$, Walters $M$. An analysis of the phagocytic potential of multinucleate foreign body giant cells. Am J Pathol 1975: 78: 343.

34. Steinar G, Ghosh L, Dorfman H. Ultrastructure of giant cell tumors of bone. Human Pathol 1972: 3: 569. 
This document is a scanned copy of a printed document. No warranty is given about the accuracy of the copy. Users should refer to the original published version of the material. 